\title{
STAREGI GURU PENDIDIKAN AGAMA ISLAM DALAM MENINGKATKAN KARAKTER RELIGIUS SISWA DI SMP NEGERI 14 BOGOR
}

\author{
Nurhasan ${ }^{1}$ Maemunah Sa' diyah ${ }^{2}$ \\ Muhammad Fahri ${ }^{3}$ \\ Universitas Ibn Khaldun Bogor \\ 르asann1812@gmail.com \\ ²maemunah@fai.uika-bogor.ac.id \\ fahri@fai.uika-bogor.ac.id
}

\begin{abstract}
Abstrak
Penelitian ini membahas tentang strategi guru pendidikan agama Islam dalam meningkatkan karakter religius siswa di SMP Negeri 14 Bogor. Tujuan penelitian ini yaitu: 1) Untuk mengetahui strategi guru Pendidikan agama Islam dalam meningkatkan karakter religius siswa di SMP Negeri 14 Bogor. Metode penelitian yang digunakan adalah penelitian lapangan (field research) dengan pendekatan kualitatif. Berdasarkan hasil wawancara yang dilakukan penulis dengan objek yang ada di sekolah peneliti dapat menyimpulkan beberapa strategi yang diterapkan oleh guru pendidikan agama Islam di SMP Negeri 14 Bogor, yaitu: 1) strategi pendidikan dengan tauladan, 2) strategi pendidikan dengan nasihat, 3) strategi pendidikan dengan pembiasaan, 4) strategi pendidikan dengan reward. Dan berdasarkan hasil angket keseluruhan strategi pendidikan dengan tauladan mencapai 85\%, strategi pendidikan dengan nasihat mencapai $87 \%$, strategi pendidikan pembiasaan mencapai $90 \%$, dan strategi pendidikan dengan reward mencapai $78 \%$. Dalam upaya meningkatkan karakter religius siswa, guru pendidikan agama Islam perlu meningkatkan strateginya dengan baik dan matang agar dapat membentuk karakter religius pada diri siswa. Karena tanpa adanya strategi yang baik tentu akan sulit dalam meningkatkan karakter religius siswa. Jadi, guru pendidikan agama Islam harus ditingkatkan dalam menggunakan metode dan program-program keagamaannya dan teknik pembelajaran harus ditingkatkan dalam hal kreatif, aktif, dan inovatif agar tujuan pendidikan dapat tercapai.
\end{abstract}

Kata kunci: strategi, guru PAI, karakter religius

\begin{abstract}
This study discusses the strategy of Islamic religious education teachers in improving the religious character of students in Bogor State Middle School 14. The purpose of this study are: 1) To find out the strategies of Islamic Education teachers in improving the religious character of students in Bogor State Middle School 14. The research method used is field research with a qualitative approach. Based on the results of interviews conducted by writers with objects in the school the researcher can conclude several strategies implemented by Islamic religious education teachers in Bogor State Middle School 14, namely: 1) educational strategies with examples, 2) educational strategies with advice, 3) educational strategies with habituation, 4) education strategies with reward. And based on the results of the overall questionnaire the education strategy with the model reached $85 \%$, the education strategy with advice reached $87 \%$, the habituation education strategy reached $90 \%$, and the education strategy with reward reached $78 \%$. In an effort to improve the religious character of students, Islamic religious education teachers need to improve their strategies well and mature in order to form a religious character in students. Because without a good strategy it will certainly be difficult to improve the religious character of students. So, Islamic religious education teachers must be improved in using religious methods and programs and learning techniques must be improved in terms of creative, active, and innovative so that educational goals can be achieved.
\end{abstract}

Keywords: strategy, PAI teacher, religious character 


\section{PENDAHULUAN}

Pendidikan Islam ialah usaha pendidik muslim yang bertakwa secara sadar membimbing dan mengarahkan pertumbuhan serta perkembangan kemampuan dasar peserta didik melalui ajaran Islam kearah titik titik yang maksimal. Jadi dapat disimpulkan bahwa pendidikan Islam merupakan pengajaran yang di lakukan peserta didik agar memiliki nilai-nilai yang islami dan kepribadian ahklak yang baik. Dalam sebuah lembaga pendidikan, pendidikan mencakup beberapa hal sperti yang utama guru dan peserta didik. Guru merupakan suatu profesi, yang berarti suatu jabatan yang memerlukan keahlian khusus sebagai guru dan tidak dapat dilakukan oleh sembarang orang yang di luar bidang pendidikan. Dalam sebuah kegiatan bjar mengajar guru merupakan orang yang berikan pelajaran atau keilmuan sedangkan siswa adalah orang yang menerima pembelajaran. Dalam meberikan atau mengajarkan pembelajaran kepada peserta didik, guru memerlukan pengetahuan atau keterampilan seorang guru. Karena tampa ilmu dan keterampilan dalam mendidik tidak akan membuat pembelajaran berjalan secara kondusif (Djamarah, 2012: 32).

Pendidikan bisa juga berfungsi untuk memunculkan atau menanamkan nilai-nilai karakter peserta didik. Karakter merupakan sebuah tabiat, ahlak atau budi pekerti yang membedakan seseorang dengan yang lainya, atau bisa di sebut dengan watak seseorang. Karakter peserta didik akan terbentuk dengan baik apabila dalam proses perkembanganya dia mendapatkan cukup ruang untuk mengekpresikan diri secara leluasa. Dalam ilmu Islam karakter bisa juga dikatakan dengan akhlak, akhlak diartikan juga sebagai tingkah laku, kebiasaan, perangai atau kesompanan. Imam al-Ghazali mengatakan bahwasanya akhlak adalah suatu sifat yang tertanam dalam jiwa, yang juga dapat melahirkan suatu perbuatan yang mudah untuk dilakukan (Mahjuddin,
2010: 2). Jadi bisa dikatakan bahwasanya karakter merupakan sifat yang tertanam pada diri seseorang, yang mencerminkan kepribadian seseorang tersebut.

Strategi merupakan suatu pola yang direncanakan dan di tetapkan secara sengaja oleh pendidik untuk melakukan kegiatan atau tindakan yang ingin dilakukan dalam pembelajaran (Majid, 2014: 7). Strategi juga bisa dikatakan sebagai hasil pemikiran seseorang terhadap analisis objek yang terjadi karena ada sesuatu yang ingin di capai atau di penuhi, makna ini juga dapat diartikan sebagai rencana yang cermat tentang kegiatan yang akan dicapai secara khusus. Guru PAI harus mempunyai sebuah strategi dalam peroses mengajar untuk memberikan pengetahuan kepada siswa. Mengajarkan dan menanamkan nilai nilai karakter, agar siswa dapat memiliki karakter yang di harapkan. Jadi jika guru atau pendidik ingin menanamkan karakter religious kepada peserta didik maka guru memerlukan strategi yang matang agar tujuan yang dicapai bisa berjalan dengan baik dan maksimal.

Sesuai dengan masalah yang penulis hadapi, maka ada tujuan-tujuan tertentu yang ingin di capai dalam tujuan ini, adapun tujuan yang ingin dicapai adalah Untuk mengetahui strategi Guru Pendidikan Agama Islam dalam meningkatkan karakter religius siswa di SMP Negeri 14 Bogor. Guru PAI harus mempunyai sebuah strategi dalam peroses mengajar untuk memberikan pengetahuan kepada siswa. Mengajarkan dan menanamkan nilai nilai karakter, agar siswa dapat memiliki karakter yang di harapkan. Jadi jika guru atau pendidik ingin menanamkan karakter religius kepada peserta didik maka guru memerlukan strategi yang matang agar tujuan yang dicapai bisa berjalan dengan baik dan maksimal. Pada umumnya salah satu permasalahan peserta didik di sekolah yaitu kurangnya karater religius yang ada pada diri siswa. Seperti kurangnya sopan 
santun, ahlak, kepribadian yang baik dan sebagainya yang menyebabkan karakter mereka menjadi tidak baik. Oleh karna itu, peneliti ingin melakkan penelitian terhadap peningatan karakter religius siswa khususnya pada siswa SMP yang dimana pembelajaran agama Islam mungkin hanya dua sampai 3 kali dalam seminggu yang menyebabkan siswa tidak memahami pembelajaran agama Islam yang sangat penting. Karna yang seharusnya terjadi para siswa itu berhasil dalam meningkatkan karakter religius mereka di sekolah, karena jika siswa dapat meningkat dalam hal kereligiusannya maka dapat dinyatakan bahwa guru PAI tersebut berhasil dalam proses pembelajarannya.

\section{METODE}

Dalam penelitian ini,
menggunakan penelitian
Penelitian kualitatif merupakan metode penelitian yang berlandaskan pada suatu filsafat postpositivisme, yang dilakukan untuk meneliti pada suatu obyek yang alamiah, yang dimana peneliti merupakan instrument kunci, tenik pengumpulan data dilaksanakan secara gabungan, analisis data bersifat induktif/kualitatif, dan hasil penelitian kualitatif akan lebih menekankan makna dari pada generalisasi (Sugiono, 2011: 9). Penelitian kualitatif adalah suatu penelitian yang ditunjukan untuk mendeskripsikan dan menganalisis fenomena, peristiwa, aktivitas sosial, sikap, kepercayaan, persepsi, pemikiran orang secara individual maupun kelompok. Penelitian kualitatif bersifat induktif artinya peneliti membiarkan permasalahanpermasalahan muncul dari data atau dibiarkan terbuka untuk interprestasi. Data dihimpun dengan pengamatan yang saksama, mencakup deskripsi dalam konteks yang mendetail disertai catatancatatan hasil wawancara, serta hasil analisis dokumen dan catatan-catatan (Sutopo, 2010: 1).

Dalam penelitian ini peneliti akan mendeskripsikan bagaimana strategi guru
PAI dalam meningkatkan karakter regius siswa di SMPN 14 Bogor. Dalam penelitian kualitatif ada hal penting yaitu bagaimana peneliti mampu merumuskan beberapa kategori permasalahan sebagai konsep yang pungsinya untuk memperbandingkan suatu data. Penelitian kualitatif bisa mengeksplorasi suatu sikap, prilaku dan pengalaman responden yang menggunakan metode interview dan focus group (Firdaus, 2012: 35).

\section{HASIL DAN PEMBAHASAN}

Berdasarkan hasil penelitian yang peneliti lakukan di SMP Negeri 14 Bogor mengenai strategi guru pendidikan agama Islam dalam meningkatkan karakter religius siswa di SMP Negeri 14 Bogor. Peneliti memperoleh data sesuai dengan strategi guru pendidikan agama Islam yang diterapkan di sekolah, yaitu bahwasanya strategi itu sangat penting dalam pembelajaran, di dalam kelas maupun di luar kelas. Seorang guru harus memiliki strategi yang baik dan efektif. Dan berdasarkan penelitian yang peneliti lakukan di SMP Negeri 14 Bogor, peneliti dapat memperoleh beberapa data dari hasil pengamatan dan wawancara dengan objek penelitian. Bahwa guru pendidikan agama Islam memiliki strategi untuk meningkatkan karakter religius siswa di SMP Negeri 14 Bogor, adapun strateginya adalah sebagai berikut:

a) Pendidikan Dengan tauladan

Dalam pendidikan itu terdapat metode keteladanan atau uswah, metode keteladanan ini sudah terjamin dan sudah diterapkan oleh Nabi kita Nabi Muhammad SAW. Nabi Muhammad SAW di utus Oleh Allah SWT itu untuk menyempurnakan akhlak, dengan suri teladan yang Rosul miliki. Rosulullah $S A W$ menyebarkan Agama Islam itu dengan ketauladananya sehingga banyak orang yang masuk ke agama Islam ini sampai sekarang. Berdasarkan hasil wawancara sebagaimana yang 
dikatakan Ibu Iis Suhartini guru pendidikan agama Islam, bahwasanya beliau mengatakan dengan strategi teladan atau uswah dapat menjadikan peserta didik meniru atau melakukan hal-hal yang baik yang dilakukan oleh kita para guru, jadi kita sebagai guru harus sudah memiliki suri teladan yang baik untuk dicontoh oleh para peserta didik. Hasil angket yang telah dibagikan kepada siswa, peneliti memperoleh hasil dari pendidikan dengan teladan atau uswah mencapai $85 \%$, pernyataan yang tertulis dalam angket ini seperti Guru pendidikan agama Iskam adalah contoh teladan yang baik, Guru pendidikan agama Islam selalu datang tepat waktu, dan guru pendidikan agama Islam selalu bertanggung jawab terhadap tugasnya saat mengajar.

b) Pendidikan Dengan Nasihat Pendidikan dengan nasihat merupakan pendidikan yang sering dilakukan oleh guru-guru di SMPN 14 Bogor. Menasihati merupakan tugas semua guru, bukan hanya guru pendidikan agama Islam saja. Menasihati itu perlu dilakukan dengan hati yang tulus, karena kalau sebagai guru menasihati peserta didiknya dengan hati pasti akan mudah diterima oleh hati peserta didiknya juga. Oleh sebab itu nasihatilah peserta didik dengan hati yang lapang, perkataan yang lemah lembut, dan dengan kasih sayang, agar mudah diterima oleh peserta didiknya. Berdasarkan wawancara yang telah dikatakan oleh bapa Ari Setiadi guru pendidikan agama Islam, bahwasanya beliau mengatakan dengan nasehat yang kita berikan terhadap peserta didik akan membuat peserta didik itu sadar akan perilaku yang baik dan buruk. Angket yang di bagikan kepada siswa-siswi, peneliti telah memperoleh hasil dari pendidikan dengan nasihat mencapai $87 \%$, yang dimana pernyataan yang ada didalam angket tersebut yaitu saat pembelajaran di dalam kelas guru pendidikan agama Islam memberikan nasihat terbaik kepada peserta didik, dan guru pendidikan agama Islam memberikan solusi atas permasalahan siswa.

c) Pendidikan Dengan Pembiasaan

Pendidikan dengan pembiasaan merupakan strategi yang dilakukan oleh guru-guru SMP Negeri 14 Bogor terutama guru Pendidikan Agama Islamnya. Karena pendidikan yang dilakukan dengan pembiasaan merupakan cara yang sangat efektif dalam membentuk akhlak mulia, keimanan, serta karakter yang baik pada siswa. Dengan pembiasaan yang baik yang diterapkan di sekolah maka akan membentuk prilaku serta sikap siswa secara bertahap menuja sikap yang baik yang sudah ditujukan. Berdasarkan hasil wawancara yang telah dikatakan oleh ibu Ineka Hartati guru pendidikan agama Islam, bahwasanya dengan pembiasaan yang diberikan kepada peserta didik dapat menumbuhkan sebuah karakter yang baik, jika pembiasaan tersebut baik. Angket yang telah dibagikan dilapangan kepada stiap siswa, disini peneliti memperoleh hasil dari pendidikan dengan pembiasaan mencapai $90 \%$. Pernyataan yang tertulis didalam angket seperti membaca AlQuran setiap hari dapat meningkatkan karakter religious siswa, kultum dapat meningkatkan karakter religious siswa, sebelum pembelajaran dipimpin doa terlebih dahulu oleh ketua kelas, siswa datang kesekolah tepat waktu, dan guru PAI menerapkan senyum, salam, sapa, dan salaman.

\section{d) Pemberian Reward}

Strategi pemberian reward atau pemberian hadiah merupakan stategi yang mesti diterapkan, harapan agar peserta didiknya memiliki motivasi untuk mendapatkanya dan dapat berlomba-lomba dalam kebaikan. Hadiah itu tidak mesti berupa uang, 
benda, dan penghargaan, melainkan bisa juga berupa dengan senyum yang tulus, pujian yang menyenangkan dan lain-lain. Berdasarkan hasil wawancara yang telah dikatakan oleh ibu Dwi Ratni Handayani wakasek kesiswaan, bahwasanya dengan kita memberikan reward kepada peserta didik dapat membuat motivasi belajar peserta didik meningkat, serta menumbuhkan persaingan dalam pembelajaran. Anket yang telah dibagikan kepada siswasiswi, peneliti telah mendapatkan hasil dari pemberian reward mencapai $78 \%$, dari pernyataan yang tertulis di dalam angket yaitu sekolah memberikan penghargaan baik materi maupun non materi kepada peserta didik yang rajin dalam mengikuti agenda keagamaan.

\section{KESIMPULAN}

Berdasarkan hasil penelitian tentang Strategi Guru Pendidikan Agama Islam Di SMP negeri 14 Bogor, maka peneliti dapat menyimpulkan sebagai berikut:

1. Strategi guru pendidikan agama Islam dalam meningkatkan karakter religius siswa di SMP Negeri 14 Bogor. Terdapat beberapa strategi yang di lakukan oleh guru pendidikan agama Islam di SMP Negeri 14 Bogor, adalah sebagai berikut:

2. Berdasarkan dari hasil wawancara dan angket keseluruhan, peneliti dapat menyimpulkan beberapa strategi yang diterapkan oleh guru penidikan agama Islam di SMP Negeri 14 Bogor, yang pertama adalah strategi pendidikan dengan tauladan sebagaimana yang dikatakan Ibu Iis Suhartini guru pendidikan agama Islam, bahwasanya beliau mengatakan dengan strategi teladan atau uswah dapat menjadikan peserta didik meniru atau melakukan hal-hal yang baik yang dilakukan oleh kita para guru, jadi kita sebagai guru harus sudah memiliki suri teladan yang baik untuk dicontoh oleh para peserta didik. Dan hasil angket nya memiliki jumlah rata-rata mencapai $85 \%$.

3. Strategi yang kedua adalah pendidikan dengan nasehat, sebagaimana yang telah dikatan oleh bapa Ari Setiadi guru pendidikan agama Islam, bahwasanya beliau mengatakan dengan nasehat yang kita berikan terhadap peserta didik akan membuat peserta didik itu sadar akan perilaku yang baik dan buruk. Dan hasil angketnya memiliki jumlah rata-rata mencapai $87 \%$.

4. Strategi yang ketiga adalah pendidikan dengan pembiasaan, sebagaimana yang telah dikatakan oleh ibu Ineka Hartati guru pendidikan agama Islam, bahwasanya dengan pembiasaan yang diberikan kepada peserta didik dapat menumbuhkan sebuah karakter yang baik jika pembiasaan tersebut baik. Dan hasil angketnya memiliki jumlah ratarata mencapai mencapai $90 \%$.

5. Dan srategi yang keempat adalah sebuah pemberian reward atau pemberian hadiah, sebagaimana yang telah dikatakan oleh ibu Dwi Ratni Handayani wakasek kesiswaan, bahwasanya dengan kita memberikan reward kepada peserta didik dapat membuat motivasi belajar peserta didik meningkat, serta menumbuhkan persaingan dalam pembelajaran. Dan hasil angketnya memiliki jumlah ratarata mencapai $78 \%$.

\section{DAFTAR PUSTAKA}

Djamarah, S.B. (2012). Prestasi Belajar dan Kopotensi Guru, Surabaya: Usaha Naional.

Firdaus, A. (2012). Metode Penelitian, Tanggerang Selatan: Jelajah Nusa.

Majid, A. (2014). Strategi Pembelajaran, Bandung: PT Remaja Rosdakarya.

Mahjuddin. (2010). Akhlaq Tasawuf II, Jakarta: Kalam Mulia.

Sugiono. (2016). Metode Penelitian Kuantitatif, Kualitatif Dan $R \& D$, Bandung: Alfabeta. 
Sutopo, A.H. \& Arief, A. (2010). Terampil Mengolah Data Kualitatif Dengan
NVIVO, Jakarta: Prenada Media Group. 